Acta vet. scand. $1960,1,114-120$.

From the Veterinary Bacteriological Laboratory, Västerås, and the State Bacteriological Laboratory, Stockholm, Sweden.

\title{
STUDIES ON STAPHYLOCOCCAL MASTITIS IN AN INDIVIDUAL HERD WITH SPECIAL REFERENCE TO PHAGE-TYPES OF ISOLATED STAPHYLOCOCCI
}

By

H. Thörne and G. Wallmark.

In studies of staphylococci isolated from bovine mastitis a predominance of strains with an identical phage-pattern has been demonstrated in some herds $(1,4)$. This was also the case in the investigation on phage-pattern and sensitivity to penicillin, which the present writers have published earlier (8). In one herd (E) all the fourteen isolated strains belonged to the same phage-type (phage-group III); all were resistant to penicillin and produced penicillinase. In the investigation reported here the presence of staphylococci in this herd was studied by repeated sampling. The purpose was to study any variations in the staphylococcal flora in the udders and to ascertain the spread of the bacteria among the personnel, in the milking machines, etc.

Herd $\mathrm{E}$ is made up of a total of 34 cows. The general hygiene in the stable, the care of the animals and the milking technique are to be regarded as satisfactory. The status of the udders in the herd was during the years 1952-1957 followed by half-yearly clinical and bacteriological examinations. In the first years a small number of cases of mastitis with findings of streptococci in the secretion occurred. These were treated with penicillin. From 1954 to 1957 only sporadic cases of streptococcal mastitis occurred and penicillin treatment has lately been applied only to a small extent. In the past few years, however, staphylococci have been demonstrated in the milk from one or more quarters in some ten cows. The clinical changes in the secretion were in most cases moderate, and clear palpable changes occurred in only a small number of cows. There have occurred, however, a 
few cases of acute staphylococcal mastitis, of which at least two terminated in death. The recovered strains of staphylococci gave a positive result for the coagulase, the mannite, and the CAmP test (7).

\section{BACTERIOLOGICAL TECHNIQUE}

Specimens of milk were taken as quarter samples after the teat had been freed from contaminating matter and disinfected, and the first milk in the teat had been removed. The samples were inoculated on blood-agar, directly as well as after enrichment by Hotis' method. Samples from the nose, the throat and the hands of the personnel (two persons), from the skin of the udders, from tubing and teat cups of the milking machines, the floor of the stalls, etc., were taken by means of swabs which, when necessary, were moistened with sterile saline. These samples were inoculated on blood-agar and on phenol-manniteagar as devised by Chapman. All the plates were incubated at $37^{\circ} \mathrm{C}$. For examination of the occurrence of bacteria in the air a number of uncovered blood-agar plates were set out in different places in the stable. After exposure for 1 hour the plates were incubated.

Suspect staphylococcal colonies were subcultured and tested by the coagulase, the mannite, and the CAMP test (7). The coagulase-positive strains were tested against the following phages: 29, 52, $52 \mathrm{~A}, 79,80,3 \mathrm{~A}, 3 \mathrm{~B}, 3 \mathrm{E}, 55,71,6,7,42 \mathrm{E}, 47,53,54,70$, $73,75,77,42 \mathrm{D}, \mathrm{KS} 6,819,1034,166,155$. The sensitivity to antibiotics was determined by the technique devised by Ericsson et al. (2). The antistaphylolysin titre was estimated by a previously described technique $(6)$.

\section{RESULTS}

At the first examination (Dec. 3, 1956) 14 coagulase-positive strains from as many quarters were isolated from 9 cows. All these strains showed identical phage-patterns, 6/47/53/54/75/ $819 / 1034+$ (phage-group III). All were resistant to penicillin and produced penicillinase.

At the next examination, on Oct. 14, 1957, 17 coagulase-positive strains were isolated from as many quarters in 11 cows of the herd. All but one, which was non-typable, showed, as before, the phage-pattern $6 / 47 / 53 / 54 / 75 / 819 / 1034+$. All were resistant to penicillin but sensitive to other common antibiotics. 
At further examination on March 13, 1958, coagulase-positive staphylococci were isolated from 12 quarters in 9 cows. All the strains showed the phage-pattern 6/47/53/54/75/819/1034+; all were resistant to penicillin and produced penicillinase.

On Nov. 12, 1957, specimens were taken from the personnel, from the skin of the udders in six of the cows that had previously been positive for staphylococci, and from the floor of the stalls. Coagulase-positive staphylococci were isolated from the hands of one of the keepers and from the skin of the udders in 3 cows. All these udder strains were identical with the previously observed strains, while the strain isolated from the keeper's hands showed the phage-pattern $52 / 79$ weak.

On Nov. 28, 1957, specimens were collected from the hands, the nose and the throat of the personnel, from the skin of the udders in 4 cows, and from the floor of the stalls. Specimens were also taken from the inside of the short as well as the long tubing and the teat cups of the milking machines. The latter specimens were taken after the milking equipments had been cleaned by thorough washing for which they were dissembled. Coagulase-positive staphylococci were isolated from the skin of the udder in one of the four cows, from the floor of the stalls and from the tubing and the teat cups. Five to ten colonies from each sample with positive finding were tested against the phages, a total of 43 colonies. On this occasion, too, all showed the phagepattern $6 / 47 / 53 / 54 / 75 / 819 / 1034+$.

On Dec. 10, 1957, further specimens were taken, this time from the hands, the nose and the throat of the personnel, from short tubing after thorough washing of the dissembled parts, from the skin of the udder in one cow, and from the floor behind the cows. In addition a number of uncovered blood-agar plates were placed out. Coagulase-positive staphylococci were this time isolated from the thumb and the nose of one keeper, from the tubing of the machine, and from the skin of the udder, while no such colonies were observed on the uncovered blood-agar plates. A total of 39 colonies from these samples were tested against the phages. As before, all the strains showed the phage-pattern $6 / 47 / 53 / 54 / 75 / 819 / 1034+$, and all were resistant to penicillin but sensitive to other antibiotics.

Besides coagulase-positive staphylococci a fairly profuse growth of other organisms, mainly coliform bacteria, coagulasenegative staphylococci and $B$. subtilis, was observed in most of 
the specimens from the skin of the udder, the floor of the stalls, and the milking machines.

On Oct. 14, 1957, blood samples were taken from all the cows for estimation of the antistaphylolysin titre. On the basis of the clinical and the bacteriological findings the cows were divided into four groups, as will be seen in Table 1, which gives the antistaphylolysin titre in each group.

T able 1.

Antistaphylolysin titres in 34 cows, correlated with clinical and bacteriological findings.

\begin{tabular}{|c|c|c|c|c|c|c|}
\hline \multirow{2}{*}{$\begin{array}{l}\text { Clinical and bacteriological } \\
\text { tindings in secretions }\end{array}$} & \multirow{2}{*}{$\begin{array}{l}\text { No. of } \\
\text { cows }\end{array}$} & \multicolumn{5}{|c|}{ Antistaphylolysin titre, $\mathrm{U} / \mathrm{ml}$. serum } \\
\hline & & $<\mathbf{0 . 3 6}$ & $0.36-1.0$ & $1.1-20$ & $2.2-4.0$ & $4.4-8.0$ \\
\hline $\begin{array}{l}\text { Toxigen. staph. and } \\
\text { clin. changes }\end{array}$ & 9 & & 3 & 2 & 2 & 2 \\
\hline $\begin{array}{l}\text { Toxigen. staph. but } \\
\text { no clin. changes }\end{array}$ & 2 & & 1 & 1 & & \\
\hline $\begin{array}{l}\text { Clin. changes and } \\
\text { other microorganisms } \\
\text { (no toxigen. staph.) }\end{array}$ & 7 & 1 & 5 & & & 1 \\
\hline $\begin{array}{l}\text { No toxigen. staph., } \\
\text { no clin. changes }\end{array}$ & 16 & 4 & 11 & & 1 & \\
\hline
\end{tabular}

\section{DISCUSSION}

The occurrence of coagulase-positive staphylococci in quarter samples in a herd comprising 34 cows was studied by means of repeated examinations. On the first occasion samples from 14 quarters in 9 cows yielded growth of coagulase positive staphylococci. All these strains showed identical phage pattern, i. e. $6 / 47 / 53 / 54 / 75 / 819 / 1034+$ (phage group III)

Ten months later coagulase positive staphylococci were found in the samples from 17 quarters in 11 cows. All these strains save one were of the same phage-type and identical with those observed previously. By further examination after another five months staphylococci were demonstrated in 12 quarters in 9 cows. All the strains showed identical phage-pattern and were also now identical with those isolated earlier. Strains of identical phage-type were also isolated on repeated occasions from the skin of the udders, from the floor of the stalls, and from tubings and teat cups of the milking machines. 
Nine of the 11 animals which were positive for staphylococci exhibited clinical signs of mastitis.

The personnel consisted of two men. Samples from one of them were throughout negative. In the other, staphylococci of the same phage-type were on one occasion isolated from the nose and the skin of one hand. On another occasion staphylococci of a different phage-type were isolated from his hand.

There was thus a heavy predominance of a characteristic phage-type among the recovered strains, which strongly suggests that there was a common source of infection. It is not known how the infection has found its way into the stable. The explanation may be either that an infected animal has been brought into the herd, or that one of the men tending the cows has been infected with the organism and has transmitted it to the udders of the cows. The conditions would then favour the spread of the infection. A stable represents a closed unit, similar to a hospital ward. It has been repeatedly shown that a staphylococcal infection that has been brought into a ward will easily spread among the patients via the personnel, various articles used in common, the air and dust, etc.. Similar conditions seem to exist in a stable. A cow with staphylococcal mastitis discharges infectious secretion. The bacteria in the discharge may then be transmitted, by air- and dust-borne infection, to other cows, and in tending an infected animal the personnel may get their hands contaminated and by direct contact transmit the bacteria to other animals. A still more important rôle in the spread of the infection is probably played by the milking equipment, as has also been pointed out earlier $(3,5)$. In milking, the animals are brought into close contact with the machines. If staphylococcal infection is present in one udder, the machine will easily become contaminated and may spread the bacteria to other cows in the herd.

Although the cleaning procedure applied at the farm was fully satisfactory, according to generally accepted standards, abundant staphylococci were demonstrated in teat cups and tubings after the machines had been cleaned.

To reduce the risk of spread of staphylococcal infection in a herd great attention must be paid to the handling and the disinfection of the milking equipments. Those animals that discharge staphylococci in the milk should be milked last. High standards should be set for the hygienic conditions in the stable and the personal hygiene of those tending the animals. 


\section{REFERENGES}

1. Edwards, S. J. and Rippon, J. E.: J. comp. Path. 1957, 67, 111.

2. Ericsson, H., Högman, C. and Wickman, K.: Scand. J. clin. Lab. Inv. 1954, 6 suppl. 11.

3. Krüger, L., Roeder, G. und Hinrichsen, J. K.: Milchwissenschaft $1953,8,150$.

4. Price, P., Neave, F. K., Rippon, J. E. and Williams, R. E. O.: J. Dairy Res. 1954, 21, 342.

5. Spencer, G. R. and Lasmanis, J.: Amer. J. vet. Res. 1952, 13, 500.

6. Thörne, $H .:$ Nord. Vet.-Med. 1958, 10, 63 .

7. Thörne, H.: Bovin mastit med fynd av stafylococcer i sekretet. Sthlm. 1958.

8. Wallmark, G. and Thörne, H.: Nord. Vet.-Med. 1958, 10, 76.

\section{SUMMARY}

Reference is made to an earlier investigation on phage types of staphylococci isolated from the secretions in a number of herds. In some of these herds there was a predominance of staphylococci with an identical phage-pattern. In the present paper the results obtained by repeated sampling during a period of 16 months in one of these herds are reported.

Coagulase-positive strains of staphylococci isolated from the udder secretions were practically consistently of a uniform phage type $(6 / 47 / 53 / 54 / 75 / 819 / 1034+)$. Identical strains were also repeatedly demonstrated on the skin of the udders, on the floor of the stalls, and on tubings and teat cups of the milking machines. Staphylococci of the same type were also on one occasion found in the nose and on the hand of one member of the staff. 9 out of 11 cows with a positiv finding of staphylococci showed clinical signs of mastitis.

Thus the origin of the infection seems to be common. The mode of spreading of the bacteria in the herd is discussed. The main rôle is attributed to the milking equipment. Measures to prevent the spreading are mentioned.

\section{ZUSAMMENFASSUNG}

Untersuchungen über Staphylokokkenmastitis in einem einzelnen Bestande, mit besonderer Berücksichtigung des Phagentyps der isolierten Staphylokokken.

Bei einer früheren Untersuchung über Phagentypen bei Staphylokokken, die aus dem Eutersekret in einer Anzahl von Beständen isoliert worden waren, wurde in einigen von diesen eine Dominanz von Staphylokokken mit identischem Phagenmuster nachgewiesen. In der vorliegenden Arbeit wird über die Resultate berichtet, die bei wiederholter Probenentnahme in einem von diesen Beständen während einer Zeit von 16 Monaten erhalten wurden.

Aus dem Eutersekret isolierte koagulasepositive Staphylokokkenstämme waren, praktisch genommen, konstant von einem einzigartigen 
Phagentyp $(6 / 47 / 53 / 54 / 75 / 819 / 1034+)$. Identische Stämme wurden auch in wiederholten Fallen auf der Euterhaut, auf dem Schemel sowie in den Schläuchen und Zitzenhülsen der Melkmaschinen ermittelt. Staphylokokken desselben Typs wurden ferner in einem Fall in der Nase und auf der einen Hand bei einem der Pfleger festgestellt. 9 von 11 Kühen mit positivem Staphylokokkenbefund zeigten klinische Anzeichen für Mastitis.

Die Infektion scheint somit einen gemeinsamen Ursprung gehabt zu haben. Die Art für die Verbreitung der Bakterien im Bestande wird diskutiert. Die wichtigste Rolle wird den Melkaggregaten zugeschrieben. Die Massnahmen zur Verhinderung der Verbreitung werden berïhrt.

\section{SAMMANFATTNING}

Undersökningar över stafylokock-mastitis $i$ en enstaka besättning med särskild hänsyn till de isolerade stafylokockernas fagtyp.

Vid en tidigare undersökning över fagtyper hos stafylokocker isolerade från juversekret $i$ ett antal besättningar påvisades $i$ några av dessa en dominans av stafylokocker med identiskt fagmönster. I föreliggande arbete redovisas de resultat, som erhållits vid upprepad provtagning i en av dessa besättningar under en tid av 16 månader.

Koagulaspositiva stafylokockstammar isolerade från juversekret voro praktiskt taget konstant av en ensartad fagtyp (6/47/53/54/75/ $819 / 1034+$ ). Identiska stammar påvisades också vid upprepade tillfällen på juverhud, på båspall samt i mjölkningsmaskinernas slangar och spenkoppar. Stafylokocker av samma typ påvisades också vid ett tillfälle i näsan och på ena handen hos en av skötarna. 9 av 11 kor med positivt stafylokockfynd visade kliniska tecken på mastit.

Infektionens ursprung synes sålunda vara gemensam. Sättet för bakteriernas spridning i besättningen diskuteras. Den viktigaste rollen tillskrives mjölkningsaggregaten. Åtgärder för att förhindra spridningen beröras.

(Received September 5. 1958). 